\title{
Redaksioneel
}

\section{Nuus van die Fakulteit Teologie (Afd A), Universiteit van Pretoria}

Die Fakulteit Teologie (Afdeling A, Nederduitsch Hervormde Kerk van Afrika) is die kleinste van al die Fakulteite aan die Universiteit van Pretoria. Die beroepsgerigte opleidingsprogram is ontwerp om predikante vir die Nederduitsch Hervormde Kerk op te lei en terselfdertyd die teologiese wetenskapbeoefening te dien en te bevorder. Die program word behartig deur 'n deeltydse dekaan wat ook departementshoof is en twaalf voltydse dosente (waarvan twee vakant is), bygestaan deur 'n aantal hulpdosente op deeltydse basis.

$\mathrm{Na}$ 'n vrugbare dienstyd as dekaan, wat oor sewentien jaar gestrek het, het prof BJ Engelbrecht op 30 September 1987 uitgetree as dekaan. Hy aanvaar emeritaat aan die einde van 1988. Die Fakulteit is baie dank verskuldig aan hierdie akademikus wat oor 'n breë terrein in Universiteit, Kerk en samelewing ' $n$ leiersrol gespeel het. Prof JP Oberholzer is aangewys as die nuwe dekaan. Sy leiding is besig om die missie van die Universiteit, naamlik die strewe na uitnemendheid, 'n werklikheid te laat word in die lewe van die Fakulteit.

\section{AKADEMIESE PROGRAM}

Toelating tot die driejarige BD-graadstudie geskied op grond van 'n afgehandelde BA-graad met voorgeskrewe vakvereistes. Die BD-studie het ten doel om kandidate vir die evangeliebediening te lewer met só 'n akademiese en professionele opleiding en toerusting dat hulle in staat sal wees om die amp van herder en leraar en die pligte en eise wat daaruit voortvloei, waardig en verantwoordelik te volvoer. Behoorlike kurrikulering het plaasgevind en deur voortgesette skoling word die aanbieding van die onderrig so effektief moontlik gemaak. Nagraadse studie, op M- en D-vlak, is voluit gerig op opleiding in gespesialiseerde teologiese kennis en navorsing.

\section{NAVORSING}

Met 'n beperkte personeel wat die sewe departemente moet behartig, stel die navorsingskomponent steeds hoë eise. Nogtans is daar 'n 
verskeidenheid lopende navorsingsprojekte en getuig die publikasies deur fakulteitslede van besondere navorsingsaktiwiteite. Gedurende 1987 is 23 artikels in gekeurde tydskrifte geplaas en daarnaas nog 38 bydraes in boeke en tydskrifte van populêr-wetenskaplike aard. Die Fakulteit het deel aan die opgrawingswerk by die Bybelse stad Lagis, die internasionale Calvynstudie en die studieprojek van die Internasionale Vereniging vir Nuwe-Testamentiese Studie. Personeel van die Departement Nuwe-Testamentiese Wetenskap het gedurende 1987 akademiese besoeke afgelê by die Georg-August Universiteit in Göttingen (Wes-Duitsland) en die Theologische Hochschule in Wes-Berlyn. In 1988 is die Universiteit van Sheffield en die Universiteit van Cambridge in Engeland, en die Katholieke Universiteit van Leuven in België besoek. Lesings is gelewer en aan 'n seminaar is deelgeneem.

Besondere prestasies is behaal deur twee studente van die Departement Kerkgeskiedenis, naamlik dr SP Pretorius wat vir sy proefskrif die SP Engelbrecht-erepenning vir SA Kerkgeskiedskrywing (goud) ontvang het, en ds LJ Strauss wat dieselfde penning in brons vir sy BD-skripsie ontvang het.

\section{GEMEENSKAPSDIENS}

Vanweë sy aard is die Fakulteit intensief betrokke by die lewe en werk van die Nederduitsch Hervormde Kerk. Lede van die Fakulteit het sitting in bestuursliggame en adviesrade van die Kerk. Deur prediking, advies, voordragte, geskrifte en die SAUK, lewer al die fakulteitslede 'n groot bydrae tot die godsdienstige peil in die Kerk en die samelewing. Die Sentrum vir Voortgesette Teologiese Toerusting, wat deur die Fakulteit in samewerking met die Kerklike Instituut vir Toerusting van Ampsdraers en Lidmate (KITAL) bedryf word, het in 1987 op dreef gekom en vyf kursusse aangebied, naamlik Gemeentelike Praktyk, Pastoraat, Presbiteraat, Opsig en Tug en Bybelstudie. Lede van die Fakulteit het steeds deel in die voortgesette hersiening van die nuwe Afrikaanse Bybelvertaling en die werk aan 'n nuwe Psalmberyming. Die nuwe Diensboek van die Nederduitsch Hervormde Kerk is hoofsaaklik deur lede van die Fakulteit saamgestel. Die nuwe reeks kategeseboeke van die kerk is ook beplan en voorberei onder leiding van Fakulteitslede in samewerking met KITAL. 


\section{SIMPOSIUMS EN SEMINARE}

Die Hermeneutiese Studiegroep in die Fakulteit is reeds goed gevestig en vervul ' $n$ besondere rol in die interdissiplinêre gesprek binne die teologie. Ook die Kerkhistoriese Genootskap van die Nederduitsch Hervormde Kerk van Afrika word vanuit die Fakulteit bedryf. Die kongres het in 1987 die Heidelbergse Kategismus as tema gehad. Lede van die Fakulteit neem deel aan die jaarlikse kongresse van vakverenigings en die byeenkomste van verskillende werk- en studiegroepe.

\section{VERNUWING EN RASIONALISASIE}

Die Fakulteit het 'n indringende ondersoek van stapel gestuur na alle aspekte van sy onderwys- en navorsingstruktuur. Die Kuratorium vir die Teologiese Opleiding het op grond van hierdie ondersoek besluit om die bestaande stelsel van 'n BA-voorstudie as toelating tot die BD-studie te handhaaf. 'n Geintegreerde teologiese studie word dus nie beoog nie. Die volgende minimumvereistes vir die BA-studie, onderhewig aan die beslissing van die Algemene Kerkvergadering in 1989, is vasgelê: Grieks en Hebreeus as hoofvakke, tweede- en derdejaarkursusse in Wysbegeerte en eerstejaarkursusse in Latyn en Duits indien laasgenoemde twee kursusse nie op matriekvlak geneem is nie. Die Algemene Kerkvergadering word versoek om ook te besluit dat die BA-studie voortaan net aan die Universiteit van Pretoria gevolg sal word.

Die Sentrum vir Voortgesette Teologiese Toerusting word uitgebrei om voorsiening te maak vir praktiese opleiding aan BD-studente sowel as aan voortgesette na-BD opleiding en gemeenskapsdiens op wyer vlak. Vir dié doel word die akademiese jaar verleng en die samewerking van praktykgeskoolde begeleiers verkry. Die Algemene Kerkvergadering sal versoek word om voortgesette opleiding ná die toetrede tot die predikantsamp verpligtend te maak vir 'n tydperk wat vasgestel word aan die hand van behoeftes en praktiese omstandighede. Praktiese opleiding en voortgesette teologiese opleiding sal op 'n paslike wyse deur die Universiteit van Pretoria erken word. Die raakpunte wat kan bestaan tussen die MDiv-studie en die voortgesette teologiese opleiding sal lei tot erkenning vir graaddoeleindes. Wat die BD-studie betref, word lesings verminder, seminare en werkswinkelbesprekings vermeerder, en die volle klem word op selfwerksaamheid gelê.

Die Kuratorium het verder die voorstel goedgekeur dat die perma- 
nent-voltydse kernpersoneel van die Fakulteit sal bestaan uit tien professore waarvan een as deeltydse dekaan sal optree. Die huidige tydelik-deeltydse hulpdosente word vervang met 'n korps buitengewone dosente wat benoem word op grond van spesialiste-kennis. Sommige van die buitengewone dosente sal behulpsaam wees met die onderrig by wyse van lesings en seminare. Ander sal met kurrikulering behulpsaam wees, met die opstel van studiegidse en die skryf van kernaantekeninge, en miskien ' $n$ beperkte lesingopdrag. Die konsekwensie van hierdie rasionaliserende maatreëls is dat twee permanentvoltydse professoraatskappe op hierdie stadium afgeskaf word. Dit geld die twee vakatures in onderskeidelik die Departemente Dogmatiek en Christelike Etiek en Praktiese Teologie. 